\title{
BRITISH MAMMALS
}

\section{THE MAMMAL SOCIETY OF THE BRITISH ISLES}

In the last issue it was announced that during a conference on British mammals organized by the University of Birmingham on 23rd to 26th April, it was proposed to launch a national society for the study of British mammals. This has now been done, and the society will be known as the Mammal Society of the British Isles. The main aim of the society will be to study the distribution, breeding biology and habits of mammals, both native and introduced, in the British Isles and in the seas surrounding them. It is hoped, for instance, to prepare at a fairly early stage a comprehensive work on British mammals comparable to The Handbook of British Birds, but not necessarily exactly modelled on it. It was made clear that the new society would not be primarily interested in the protection and conservation of mammals, which fell within the sphere of the Fauna Preservation Society, though it would always be prepared to co-operate with the F.P.S. and other interested bodies, in securing either specific or general aims in this field.

The following were elected to offices in the new society :-

President: The Earl of Cranbrook.

Chairman: Professor A. N. Worden.

Hon. Secretary: T. J. Pickvance, Department of Extramural Studies, University of Birmingham, Edmund Street, Birmingham 3.

Hon.Treasurer : H. G. Hurrell, Moorgate, Wrangaton, Devon. Hon. Secretary, Advisory Scientific Committee : H. N. Southern. Committee : Michael Blackmore, Dr. Peter Crowcroft, R. S. R. Fitter, R. M. Lockley, Dr. K. R. S. Morris, H. V. Thompson.

The annual subscription has been fixed at one guinea, and the Committee hopes that all naturalists and zoologists who are interested in the study of mammals in Britain will join the new society by getting in touch with the Hon. Secretary at the above address. 